\title{
BRITISH ACTION IN LIBYA 2011: THE LAWFUL PROTECTION OF NATIONALS ABROAD?
}

\author{
Francis Grimal $^{*}$ and Graham Melling ${ }^{+}$
}

\begin{abstract}
The forcible protection of one states' own nationals on another state's territory is one which stretches the boundaries of the broader, inherent right of self-defence available to states under international law. Known as the 'protection of nationals abroad' this doctrine is one which remains, at best, highly controversial. This Article examines the lawfulness of action taken by British forces when they rescued and evacuated British nationals prior to Libya descending into civil war. It also considers the extent to which action by British forces fits within the highly controversial paradigm of 'protection of nationals abroad'.
\end{abstract}

\section{INTRODUCTION}

The middle of February 2011 witnessed the descent into civil war of the Great Socialist People's Libyan Arab Jamahiriya. For the United Kingdom and other states arose the pressing question of how to provide for the protection and safety of their nationals based in Libya. At that time the UK government (along with other governments) made the decision that the appropriate response to the developing and increasingly violent conflict in Libya was to take steps to evacuate their nationals from harm's way. At the end of that month, British military Special Forces troops entered Libya and effected an operation to evacuate British nationals (and other nationals, as it turned out) from Libya. Apparently, for good operational reasons, the action by British Special Forces was planned and executed in secret and presumably without the consent of the Libyan government. ${ }^{1}$

\footnotetext{
* University of Buckingham, UK.

${ }^{+}$University of Buckingham, UK.

* The authors would like to thank James A Green for his very helpful comments on this article.

${ }^{1}$ D Leppard, M Smith and M Colvin "Daring SAS Raid Rescues 150 from Libyan Desert; Hostage Fear for Britons" The Sunday Times (London, February 27 2011) 1; N Meo, M Kite and P Sherwell "SAS Swoops in Dramatic Libya Rescue" The Sunday
} 
It is notable that little comment was made in the British media (or other international media outlets) with respect to the lawfulness of the intervention of British troops within a sovereign state for the purpose of evacuating its nationals without that state's consent. Moreover, in its explanation of the operation to evacuate its nationals the British government made no apparent consideration of the status of its actions within international law. This lack of comment could give the impression that such conduct - the intervention by one state in another state to effect the evacuation of its nationals without the host state's consent, the concept of 'protection of nationals abroad' - is acceptable in international law to the point of being uncontroversial. However, the question of the lawfulness or otherwise of the concept of the protection of national abroad is not uncontroversial and is not settled as lawful in international law.

The possibility in international law of a state utilising force to protect its own nationals in another state ('the protection of nationals abroad') is something which has been carefully scrutinised by commentators. ${ }^{2}$ The main debate within both the literature and the actual practice of individual states ('state practice') is whether such action is permissible under international law and, if so, on what basis. ${ }^{3}$

Broadly speaking, two perspectives on this issue predominate. On the one hand, there are those that argue that the right to protect one's nationals abroad is a species of unilateral humanitarian intervention whereas, on the other, there are those who argue that the right to protect nationals abroad is more properly a legitimate exercise of a states inherent right to self-defence. This

Telegraph (London, February 27, 2011) 1; and S McGee and J Bone "Hundreds are Still Stranded in the Desert" The Sunday Times (London, February 27, 2011) 2.

2 For example, see D W Bowett "The Use of Force for The Protection of Nationals Abroad" in A Cassese (ed) The Current Legal Regulation of the Use of Force (Dordrecht: Martinus Nijhoff, 1986); JA Green "Passportisation, Peacekeepers and Proporationality: The Russian Claim of the Protectionf of Nationals Abroad in SelfDefence" in James A Green and Christopher P M Waters (eds) Conflict in the Caucasus: Implications for International Legal Order (Basingstoke: Palgrave Macmillan, 2010), pp 54 - 79; TC Wingfield and JE Meyen Lillich on the Forcible Protection of Nationals Abroad : in Memory of Professor Richard B Lillich (International Law Studies Series, US Naval War College 2002); KE Eichensehr "Defending Nationals Abroad: Assessing the Lawfulness of Forcible Hostage Rescues Note" (2007) 48 Va J Int'l L 451; T Ruys "The "Protection of Nationals' Doctrine Revisited" (2008) 13 J Conflict Security Law 233; TC Wingfield "Forcible Protection of Nationals Abroad" (1999) 104 Dick L Rev 439; and R J Zedalis "Protection of Nationals Abroad: Is Consent the Basis of Legal Obligation" (1990) 25 Tex Int'1 L J 209.

${ }^{3}$ Green provides a useful summary of the positions taken regarding this issue. See Green above $n 2$. 
Article will confine itself to examining the development of the doctrine of protection of nationals abroad as a species/aspect of states inherent right to self-defence. ${ }^{4}$ The authors recognise that there are those commentators that argue that the protection of nationals abroad is a legitimate aspect of unilateral humanitarian intervention. ${ }^{5}$ However, as the doctrine of humanitarian intervention is at best an extremely controversial doctrine in itself, it is the authors' view that it is not the proper basis for consideration of the development of the doctrine of protection of nationals abroad. ${ }^{6}$ Moreover, as Green notes "...importantly, it is apparent that when states do make a legal claim based on the protection of nationals abroad, they do so within the rubric of self-defence." Some commentators in favour of a right to protection of nationals abroad argue that the doctrine is merely an extension of the inherent right of self-defence available to all states under international law. ${ }^{8}$ States' support for this doctrine as a manifestation of self-defence is to some extent evidenced by state practice. ${ }^{9}$ The criticisms and objections against the practice of utilising force to protect nationals are multifaceted, ${ }^{10}$ and this is something this Article will carefully scrutinise in Part III. ${ }^{11}$

The purpose of this Article is to examine whether the action taken by British troops in protecting and evacuating British nationals following the uprising against the Gaddafi regime in February 2011 was lawful under international law. This Article does not assess the lawfulness of action taken against the Gaddafi regime following the adoption of Security Council Resolutions 1970 and 1973: that is left for other commentators to consider elsewhere. The next section, Part II, provides the detail regarding the British action. Part III then examines the extent to which there is a right to protect ones nationals abroad within the broader concept of self-defence under international law. Finally, Part IV goes on to apply this legal framework to the February 2011 British intervention.

\footnotetext{
${ }^{4}$ Ibid, p 59.

5 See D J Gordon "Use of Force for the Protection of Nationals Abroad: The Entebbe Incident Note” (1977) 9 Case W Res J Int'1 L 117; and N Ronzitti Rescuing Nationals Abroad Through Military Coercion and Intervention on Grounds of Humanity (Dordrecht Martinus Nijhoff, 1985).

${ }^{6}$ See Green above n 2, p 59. Moreover, Green goes on to note: "[A] conceptual distinction should be made between such actions and those aimed at the protection of nationals abroad. One claim relates to the protection of a state's own nationals, the other to the protection of foreign nationals."

${ }^{7}$ Ibid.

${ }^{8}$ T Farer "Panama: Beyond the Charter Paradigm" (1990) 84 Am J Int'1 L 494 at505.

${ }^{9}$ See infra Part II on this point.

${ }^{10}$ Green above n 2, pp 59-63.

${ }^{11}$ See infra Part III for a complete discussion of this issue.
} 


\section{BRITISH ACTION IN LIBYA}

The British evacuation of its nationals from Libya during the early passage of the Libyan conflict was carried out by members of the British military's Special Forces; the Secret Air Service and the Secret Boat Service. In what was variously described as a 'daring' and 'dramatic' raid the two arms of the British Special Forces completed their mission in a manner befitting their famed motto "who dares wins'. ${ }^{12}$ Over the course of the weekend of $26^{\text {th }}$ and $27^{\text {th }}$ February 2011 British Special Forces carried out operations to rescue and extract British and other nationals from Libya. ${ }^{13}$ It was widely reported in the British media that members of the Special Forces had first arrived in Tripoli a number of days before the evacuation to prepare the ground for their intended mission. ${ }^{14}$ As the situation in Libya deteriorated and the threat to British nationals intensified the operation was put into gear.

Striking out from their base in Tripoli the Special Forces troops travelled extensively throughout the Libya gathering up British and other nationals to take them to pre-determined airfields under the control of anti-Gaddaffi forces and private security professionals under the pay of multinational oil companies in the area for air evacuation. ${ }^{15}$ From these extraction points British and other nationals were then flown to a British Airforce base in Malta on RAF Hercules transport planes specially equipped to support Special Forces operations. It was reported that during the final phase of the rescue gunfire was exchanged but no casualties were sustained although there was inconsequential damage to one of the aircraft from small arms fire. On landing in the Malta, the actions and success of the operation was reported by the British government and heralded as a complete success. ${ }^{16}$

In explaining its decision to authorise such an operation the UK identified the general situation in Libya as being unstable and violent giving rise to particular dangers that warranted it taking action. Clearly, the government was under pressure from public opinion and the national media to do something, and to be seen to do something, to protect British nationals. However, whilst there was a general threat of violence and danger to those living in Libya, whether Libyan or foreign nationals, there was no greater apparent threat made to British nationals or foreign nationals as had been the case with respect to the attempted rescue/evacuation by the US of its nationals from Iran

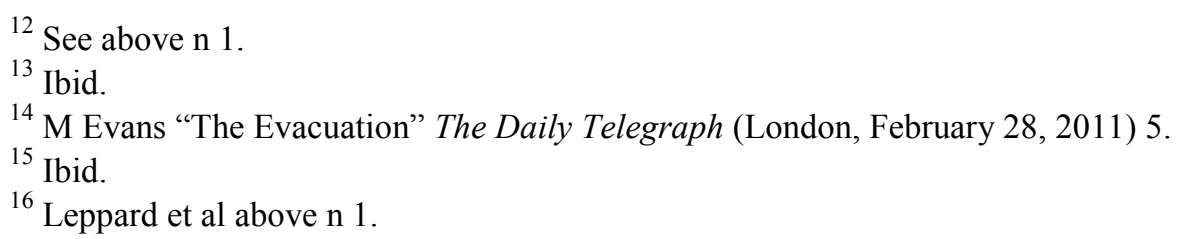


in the 1970s or the rescue of its nationals effected by Israeli Special Forces in Entebbe, Uganda. Nevertheless, from the British government's perspective the general instability and the very generalised threat of danger to foreign nationals as members of Libyan society was a sufficient justification for sending military forces onto the sovereign territory of another state without invitation. A lack of such invitation would constitute a prima facie breach of Article 2(7) of the United Nations Charter which prohibits a state intervening in another state's sovereign affairs. Technically, Article 2(7) only prohibits the United Nations from intervening in matters within a state's domestic jurisdiction. ${ }^{17}$ However, if one couples this prohibition with that contained in Article 2(4) along with the customary principle of non-intervention, then a state cannot interfere in another state's affairs. The only exception to the position within Article 2(7) is if the Security Council has sanctioned a state to deploy on another state's sovereign territory.

It is notable in both the news/media reporting and government comment that no question of the lawfulness or otherwise of such an operation was seriously raised. Moreover, in addition to the UK action, other states, including China, also undertook similar operations to evacuate nationals. Added to this there was little or no objection by the international community or Libya, suggesting a toleration of such practice despite doubts surrounding the lawfulness of these types of operations.

\section{THE PROTECTION OF NATIONALS ABROAD}

The concept of 'protection of nationals abroad' has been defined as the use of force by a state to protect its nationals that are under attack, be that actual or threatened, outside of its own territory, without the consent of the state against which force is used or the authorisation of the UN Security Council. ${ }^{18}$ As such, any arguable right to protect nationals abroad is based on a broad construction of the right of self-defence to which all states are entitled to under international law. ${ }^{19}$ This Part examines how such a right could be constructed. It first sets out the basic mechanics of self-defence and how this particular doctrine operates under international law. It then goes on to consider how a state might construct a right to protect its nationals abroad as an extension of self-defence. Finally, this Part will consider the practical

\footnotetext{
${ }^{17}$ UN Charter art 2, para 7.

18 The protection of nationals abroad is not provided for in Charter and there exists no independent doctrine of customary international law permitting such actions. See Green above note 2, p 58; and A Arend and R Beck International Law and the Use of Force: Beyond the UN Charter Paradigm (London: Routledge, 1993) p 94.

${ }^{19}$ Green above n 2, p 59.
} 
application of such a right and examine some specific instances when states have invoked the existence of such a doctrine.

It is important to note the 'default position' that any use of force by one state against another is unlawful under the strict prohibition contained in Article 2(4) of the United Nations Charter. ${ }^{20}$ Equally, one must also recall the combined effect of Article 2(7) of the United Nations Charter, Article 2(4) of the United Nations Charter and the principle of non-intervention which prohibits a state interfering within another state's domestic affairs. Prima facie, the use of force to protect nationals abroad is in clear breach of the combined effect of the provisions set out in the preceding sentence. However, international law permits two exceptions to the cardinal rule contained in Article 2(4) of the United Nations Charter. First, a state may act in selfdefence against a prior use of military force providing that it complies with certain criteria which have developed from customary international law and treaty law. ${ }^{21}$ The second exception is if the United Nations Security Council under its 'Chapter VII powers' authorises a state to use force. ${ }^{22}$ Those in favour of the doctrine of protecting nationals abroad argue that such action falls within the first exception - under a more elastic interpretation of selfdefence. $^{23}$

\section{Overview of Self-Defence}

The right of self-defence under international law has attracted considerable academic scrutiny. ${ }^{24}$ In light of that fact, this section will focus on setting out the basic conditions required for a state to invoke self-defence rather than, for example, revisiting the more contentious issues surrounding

\footnotetext{
${ }^{20}$ UN Charter art 2, para 4.

21 See Military and Paramilitary Activities in and Against Nicaragua (Nicar v US), 1986 ICJ 14, ๆ 34 (June 27).

${ }^{22}$ UN Charter art. 42.
}

${ }^{23}$ Green above $\mathrm{n} \mathrm{2,} \mathrm{p} \mathrm{61.} \mathrm{Although} \mathrm{not} \mathrm{strictly} \mathrm{in} \mathrm{favour} \mathrm{of} \mathrm{the} \mathrm{doctrine} \mathrm{of} \mathrm{the}$ protection of nationals abroad, Green allows for the conceptual possibility of such a doctrine.

${ }^{24}$ For a useful overview, see J A Green and F Grimal "The Threat of Force as an Action in Self-Defense under International Law" (2011) 44 Vand J Transnat'l L 285 at 298-302. For more detailed discussion see, for example, JA Green The International Court of Justice and Self-Defence in International Law (Oxford Hart Publishing, 2009); DW Bowett Self-Defence in International Law (Manchester: Manchester University Press, 1958); A Constantinou The Right of Self-Defence Under Customary International Law and Article 51 of the United Nations Charter (Athènes Bruxelles: Ant N Sakkoulas; Bruylant, 2000); Y Dinstein War, Aggression and Self-Defence (Cambridge: Cambridge University Press, 4th edn, 2005); CD Gray International Law and the Use of Force (Oxford: Oxford University Press, 3rd edn, 2008). 
both anticipatory and pre-emptive self-defence. ${ }^{25}$ The law governing a state's right to self-defence is a combination of both customary international law and Charter law. ${ }^{26}$ Customary principles dictate that a state acting in self-defence must do so within the parameters of necessity and proportionality: customary law principles that have been distilled from the words of US Secretary of State Webster following the well known Caroline incident, according to which a state invoking self-defence must:

"[S]how a necessity of self-defense, instant, overwhelming, leaving no choice of means, and no moment for deliberation. It will be for it to show, also, that... [it] did nothing unreasonable or excessive; since the act, justified by the necessity of self-defence, must be limited by that necessity and kept clearly within it." 27

The necessity principle dictates that a state must be left with no other nonforcible alternatives - force is to be used as a last resort. ${ }^{28}$ Proportionality simply requires the level of force used in self-defence be commensurate to the severity of the attack. ${ }^{29}$ Some commentators posit a 'restrictive' view that the cornerstone provision contained in Article 51 of the United Nations Charter overrides previous customary international law. ${ }^{30}$ The vast majority of scholars however accept that the inherent customary provisions still exist and

${ }^{25}$ On pre-emption, see generally NA Shah "Self-Defence, Anticipatory Self-Defence and Pre-Emption: International Law's Response to Terrorism" (2007) 12 Journal of Conflict Security Law 95 at 111; and C Antonopoulos "Force by Armed Groups as Armed Attack and the Broadening of Self-Defence" (2008) 55 Neth Int'l L Rev 159.

${ }^{26}$ See above $\mathrm{n} 24$ generally and in particular J A Green The International Court of Justice and Self-Defence in International Law pp 128-138.

27 Letter from Daniel Webster to Henry S Fox (Apr. 24, 1841), in 29 British and Foreign State Papers (1841-42), 1129-39 (1857). For more detailed discussion see J A Green "Docking the Caroline: Understanding the Relevance of the Formula in Contemporary Customary International Law concerning Self-Defense" (2006) 14 Cardozo J Int'l \& Comp L 429.

${ }^{28}$ Green 'Docking the Caroline' ibid at 450-457.

${ }^{29}$ See for example, J Gardam Necessity, Proportionality and the Use of Force by States (Cambridge: Cambridge University Press, 2004) p 142; and R Wedgwood "Proportionality and Necessity in American National Security Decision Making Implementing Limitations on the Use of Force: The Doctrine of Proportionality and Necessity" (1992) 86 Am Soc'y Int'l L Proc 58, at 59.

${ }^{30}$ On this debate see Gray above n 24, pp 128-160. With regard to Article 51 being a 'cornerstone' provision see Case Concerning Oil Platforms (Iran v US), 2003 ICJ 161, separate opinion of Judge Simma, at 328 ('Everybody will be aware of the current crisis of the United Nations system of maintenance of peace and security, of which Articles 2(4) and 51 are cornerstones.') 
the accepted position is that of a fusion of both customary provisions and current Charter law. ${ }^{31}$

In order for a state to invoke self-defence under Article 51 of the United Nations Charter, it must have suffered an 'armed attack'. ${ }^{32}$ The term 'armed attack' is undefined in the Charter but has been interpreted by the International Court of Justice to mean a "grave use of force". ${ }^{33}$ By way of summary, if a state has suffered an armed attack (a grave use of force) and complied with the two cardinal principles of necessity and proportionality then such action will be lawful under international law.

\section{Does a Right to Protect Nationals Exist?}

The right to protect nationals abroad has been invoked on a number of occasions in the latter part of the Twentieth Century. ${ }^{34}$ However it has not proved to be a common claim and in the main its invocation is confined to only a few states in that period. ${ }^{35}$ The supporting argument in favour of the protection of nationals abroad starts with the language of Article 51. Supporters of the existence of this right argue that the 'armed attack' element required for self-defence does not specifically require an armed attack against a state's own territory: for them an attack against the nationals of that state would suffice. $^{36}$

The assessment of what constitutes an armed attack will take into account differing factors dependent upon the nature and the context of events. As with other forms of armed attack, in order for the threshold to be met the attack against nationals would have to be 'grave'. ${ }^{37}$ Whilst a numerical measure of deaths or injuries caused to nationals might have a simplistic appeal, such an approach has been considered arbitrary. ${ }^{38}$ However, Bowett considers that there may be circumstances where a threat of danger to the nationals of a state abroad could be "great enough, or wide enough in its application, for it to be

\footnotetext{
31 Ibid.

32 D Greig "Self-defence and the Security Council: What Does Article 51 require?" (1991) 40 International \& Comparative Law Quarterly 366.

${ }^{33}$ Military and Paramilitary Activities in and Against Nicaragua, above n 23. This statement was also reemployed in the Oil Platforms decision. Case Concerning Oil Platforms (Iran v US), 2003 I C J 161, ๆ 51 (Nov 6). See also Green above n 26, pp 112 - 129; Constantinou above, n 26.

34 Gray above n 24, p 156.

35 Ibid.

${ }^{36}$ Bowett above n 2, p 43; J A Green above n 2, p 60; Eichensehr above n 2, p 469

${ }^{37}$ Green above n 2, p 60 .

${ }^{38}$ Bowett above n 2, p 43.
} 
legitimately construed as an attack on the state itself." ${ }^{39}$ Therefore the attack on a state's nationals is actually an attack on the state itself and therefore legitimatises its act of self-defence. It has additionally been suggested that the position of the national vis-à-vis his state is a factor to take into account when analysing the issue of whether the armed attack threshold has been met. Accordingly, if a national is employed by a government in an official capacity, such as an Embassy official, or a national is targeted because of their nationality and therefore 'as proxies for their national government', ${ }^{40}$ perhaps such a threat to a state's nationals is more easily characterised as the threat of an armed attack on the state itself. ${ }^{41}$

Detractors of this view object to such an argument on three grounds. ${ }^{42}$ First, the language of Article 51 is not elastic enough to stretch to including the concept of an attack against nationals. ${ }^{43}$ Secondly, there is insufficient state practice to support this concept. ${ }^{44}$ Finally, as with the concept of 'Humanitarian Intervention, ${ }^{45}$, there is a palpable fear that the development of the doctrine of protecting one's nationals abroad would lead to abuse and be utilised for nefarious purposes. ${ }^{46}$ However, in defence of the doctrine, it may be said that a close textual interpretation of Article 51 reveals that there is no explicit or even implicit requirement that an armed attack must be against the territory of a state and not merely its nationals. ${ }^{47}$ This perhaps requires a certain 'leap of faith', although any action taken in self-defence would of

\footnotetext{
${ }^{39}$ Bowett above n 24, p 93.

${ }^{40}$ Eichensehr above n 2, p 469.

${ }^{41}$ Ibid, p 469.
}

${ }^{42}$ For example, see generally I Brownlie International Law and the Use of Force by States (Oxford: Oxford University Press, 1963).

${ }^{43}$ Green above n 2, p 60; and see also M Iqbal and S Hassan 'Armed and Ready" (2008) 158 New Law Journal at 1.

${ }^{44}$ Ibid; Ronzitti above n 5, p 12; Arend and Beck above note 18 pp 106 - 110; and J Quigley "Legality of the United States Invasion of Panama," (1990) 15 Yale J Int'l L 276 at 287.

45 See generally I Brownlie International Law and the Use of Force by States (Oxford: Oxford University Press, 1963); Arend and Beck above n 18; Dinstein above n 24; Gray above n 24. For more detailed discussion, see L Henkin "Kosovo and the Law of Humanitarian Intervention" (1999) 93 Am J Int'l L 824; J I Charney "Anticipatory Humanitarian Intervention in Kosovo " (1999) 93 Am J Int'l L 834; R A Falk "Kosovo, World Order, and the Future of International Law" (1999) 93 Am J Int'l L 847.

${ }^{46}$ Green above n 2, p 60; Brownlie above n 42, p 301; Quigley above n 44, p 293.

${ }^{47}$ Ibid. See also A Randelzhofer "Article 51" in Bruno Simma (ed) The Charter of the United Nations: A Commentary (Oxford: Oxford University Press, 2002); Dinstein above n 24, p 175. 
course have to satisfy both the necessity and proportionality requirements set out in both Charter and customary international law. ${ }^{48}$

With regard to state practice, Green takes a relatively nuanced view. ${ }^{49}$ On occasions when states have objected to such a doctrine (Entebbe, Panama, Grenada and South Ossetia) their objection was not against the doctrine itself, but rather against the actual deployment of force. For example, objection to the US's incursion into both Grenada and Panama was based largely on the disproportionate amount of troops involved in order to secure the safety of the threatened nationals. ${ }^{50}$ Similarly, in both Grenada and Panama, concerns were raised that these interventions were merely a pretext for regime change. ${ }^{51}$ That aside, those criticisms (at least in Green's view) were not against the doctrine per se, but rather the way in which the US sought to invoke it. ${ }^{52}$

Equally, those states which objected to the 'Entebbe incident' in which Israel used force to liberate its nationals who were being held hostage in Uganda in 1976 were not necessarily against the doctrine per se. ${ }^{53}$ Rather, they believed that Israel had not suffered an armed attack in order to invoke Article 51, nor had it exhausted other forms of remedy such as negotiation which would satisfy the necessity requirement. ${ }^{54}$ Although Russia's forcible action against Georgia in 2008 would seem to be a clear abuse of the claim to protection of nationals abroad, ${ }^{55}$ again one could argue that this was on grounds of a disproportionate response rather than the non-existence of the right to protect its nationals. Green concedes that there is an understandable reason for rejecting the concept of such a doctrine on policy grounds in that it could lead to abuse. ${ }^{56}$ However, many actions in self-defence involving a use of force could potentially have an alternative strategic goal in mind which would not necessarily preclude such a right existing in the first place. The real difficulty in advocating the protection of nationals abroad doctrine is that it requires an initial 'leap of faith'. A state has to 'see the light' and truly believe that an armed attack on its nationals is tantamount to an armed attack on it and

\footnotetext{
${ }^{48}$ Above $\mathrm{n} 31$.

${ }^{49}$ Green above n 2, p 61.

${ }^{50}$ Ibid, pp $62-64$.

51 Ibid. See also, generally, M J Levitin "Law of Force and the Force of Law: Grenada, the Falklands, and Humanitarian Intervention" (1986) 27 Harv Int'l L J 621; and V Nanda "The Validity of United States Inervention in Panama Under International Law” (1990) 84 Am J Int'l L 494.

${ }^{52}$ Green above no 2, p 62.

53 Ibid.

54 Ibid.

55 See generally A Nußberger "The War between Russia and Georgia - Consequences and Unresolved Questions" (2009) 1 Goettingen Journal of International Law 341.

${ }^{56}$ Green above n 2, p 63.
} 
therefore falls within the purview of Article 51. Effectively, the test for determining the lawfulness of protection of nationals is a two-stage test. First, have the nationals suffered an armed attack or been threatened with one? Secondly, if the answer is 'yes' to the first stage of the test, is the response by the state both necessary and proportionate? Arguably, if a state can meet both stages of the test then its action may be deemed lawful.

\section{APPLICATION OF THE LAW TO THE BRITISH ACTION}

In order for the British evacuation of its nationals from Libya without Libyan consent to be lawful, it is necessary to consider whether the nationals had suffered an armed attack as per Article 51 of the UN Charter and whether the British response satisfied both requirements of necessity and proportionality. $^{57}$

Was the requirement of an 'armed attack' met? In respect of the British nationals in Libya no particularised threat of harm or danger materialised and certainly no actual attack on British nationals was reported. In addition to which, the nationals that were subject to the rescue were not reported to have been employed by the government in an official capacity. They were British nationals in Libya in their capacity as private individuals. This is to be contrasted with the particular threats and actual attacks suffered by the nationals of the United States in the U.S. Embassy siege and hostage taking in Iran. ${ }^{58}$ In respect of the US Embassy hostages, they were both U.S. citizens and employed by the US government as embassy staff. When attacked, they were attacked in the grounds of the US Embassy and were clearly being attacked as 'an overt proxy for the US government ${ }^{\text {, }}$ ' therefore more readily falling within a broader characterisation of 'armed attack'. It has been noted elsewhere that the more problematic situation arises where nationals are 'unaffiliated with their national state except by nationality and are seized or threatened while acting as individuals or on the behalf of their nongovernment employers. In such instances, it is less clear that an attack on an individual is intended to be a proxy attack on their national state. ${ }^{60}$ In respect of the British nationals in Libya, whatever the harm or danger that was faced, it nevertheless involved private individuals and was purely a consequence of the general breakdown of civil order within Libya; furthermore, it was not sufficiently 'grave' or specific to being a British national to meet the required

\footnotetext{
${ }^{57}$ Bowett above n 24, p 96.

${ }^{58}$ Eichensehr above n 2, p 469.

59 Ibid.

60 Ibid.
} 
threshold of constituting an 'armed attack', even within Bowett's conception. $^{61}$

The next factor to consider is whether the British intervention satisfied the conditions of necessity and proportionality. To begin, did the threat posed to British nationals necessitate British Special Forces undertaking their action? The answer would seem to be no since there was no specific threat that had been posed to British nationals other than the general dangers associated with the breakdown of civil order and the descent into civil war. Furthemore, at the time of the operation there was still the possibility of evacuating British and other nationals from Libya without the need to use British Special Forces. Civilian airlines and other forms of transportation were still operating. Therefore there would seem to be limited evidence of the requisite necessity for such an action to fall within the bounds of self-defence. Admittedly, from the British government's perspective one presumes that there would have been consideration of the planned UK involvement in the NATO operations that were to ensue. From this perspective a sensible pragmatic response to such a plan would be to remove one's nationals prior to such involvement to eliminate the likelihood of one's nationals eventually becoming a bargaining chip and propaganda weapon for the Libyan regime. However, this in itself does not mean that the removal of British nationals was a 'necessity' in terms of establishing the lawfulness of a purported self-defence action.

Did the British action meet the requirements of proportionality? The requirement of proportionality in this context means that the action taken by Britain was merely confined to evacuating its nationals from Libya. On the face of it the British action did not go beyond that which was necessary to achieve the goal of ensuring the protection and safe evacuation of its nationals. Whilst British military personnel apparently did travel extensively throughout Libya to secure the safety of British nationals and provide for their evacuation, this was completed without any reported use of force. Furthermore, the British action did not apparently involve any ulterior motivation or intent, and it may be contrasted for example with the US interventions in Grenada and Panama and the Russian intervention in Georgia. ${ }^{62}$ The British action could perhaps, therefore, be considered as complying with the proportionality requirement.

Overall, then, we would argue that the intervention by British forces was not in response to an armed attack and was not 'necessary', albeit that it was apparently proportionate. Nonetheless, due to the restricted effect of the British Special Forces operation in Libya, ie its confinement to evacuation of British and other foreign nationals, the British action seems to have been tolerated as a practical response to dangerous events unfolding in Libya. This

\footnotetext{
${ }^{61}$ See Bowett above n 24, p 93.

${ }^{62}$ See Part III.
} 
tolerant approach stems in part from the fact that the operation gave rise to no objection from the international community at large and, in particular, the Libyan government. Furthermore, in its analysis and discussion of events the British government gave no reported consideration to the question of the lawfulness of its operation. In addition to which, in as much as the doctrine of protection of nationals abroad is an aspect of a state's inherent right to selfdefence, the intervention was not reported to the United Nations Security Council by Britain (such a report would be required for self-defence under Article 51 of the UN Charter).

\section{CONCLUSION}

The British action in Libya in late February 2011, and other comparable instances of state practice, do not add anything to any purported shift in the legal paradigm concerning the protection of nationals abroad in as much as they are considered as uncontroversial and pragmatic responses to such extreme circumstances. Today, governments are generally expected to provide more extensive protection and assistance to their nationals when they are exposed to danger/threat of even a very general and non-specific kind - ie not a specific threat to nationals of a particular state as for example in Iran (v US citizens) or Entebbe (v Israeli). However, in so far as a state merely effects an evacuation short of armed intervention - such actions seem to be 'tolerated' without having legal 'effect'. Therefore such action does not constitute state practice for the purpose of a developing right under customary international law. Action such as the UK's is tolerated due to the precise and limited objective of extraction, but the toleration does not equate to the necessary intention by the majority of states that the doctrine develop as a customary right. From a practical perspective one suggestion as to why states tolerate rescue missions on their territory is that such actions help to diffuse potentially difficult situations. There is perhaps a fear that if foreign nationals remain on their territory, the 'parent' state may become more involved in their domestic affairs than would be desirable: tolerating instances of evacuation amounts to the lesser of two evils. 